Strategy for Transforming Indonesian Agriculture

Keijiro Otsuka

March , 2021

Discussion Paper No.2108

GRADUATE SCHOOL OF ECONOMICS

KOBE UNIVERSITY

ROKKO, KOBE, JAPAN 


\title{
Strategy for Transforming Indonesian Agriculture ${ }^{1}$
}

\author{
Keijiro Otsuka \\ Professor of Development Economics, Kobe University, Kobe \\ and
}

Chief Senior Researcher at the Institute of Developing Economies, Tokyo

Traditionally, a major role of agriculture in Asia was to produce enough staple foods for food security through intensification of farming system. Today, however, agriculture is expected to contribute to multiple development goals. First, since wage rate has been increasing in high-performing Asian countries, including Indonesia, farm size expansion to introduce labor-saving mechanization must be promoted to reduce production cost, particularly in rice farming. Second, considering increasing demand for palm oil and global concern with decreasing forest environment, achieving intensification of oil palm production without extensification is an urgent issue. Third, responding to increasing demand for high-value agricultural products (HVPs), such as fresh fruits and vegetables, for better nutrition and health, agricultural resources must be shifted to the production of these products. Fourth, considering that urban areas are excessively congested, rural areas must provide increased employment opportunities by promoting rural industrialization. Based on the literature review, this article proposes strategies (1) to

\footnotetext{
${ }^{1}$ I am heavily indebted to S. Suyanto of the World Agroforestry Center in Bogor for assistance and useful comments.
} 
maintain comparative advantage in rice farming, (2) to intensify oil palm production in a sustainable fashion, (3) to increase production of HVPs, and (4) to promote rural industrialization simultaneously in the context of Indonesia.

\section{INTRODUCTION}

In tropical Asia where agricultural land is generally scarce, a major role of agriculture was traditionally to ensure sufficient production of staple crops for food security. Today, however, agriculture must contribute to multiple development goals, including food security, eradiation of malnutrition, poverty reduction, employment generation, and environmental sustainability, among other things (Otsuka and Fan 2021). Indonesia is endowed with rich natural resources and its development path is unique in Asia. Indeed, since the independence Indonesian government has been concerned not only with selfsufficiency in rice production for food security but also with resource-based industrialization or encouragement of the downstream processing of tree crops, such as rubber, coffee, cocoa, and oil palm, for rural development, employment generation, and poverty reduction (e.g., Neilson and McKenzie 2016; Pramudya and Hospes 2017; Neilson et al. 2020). Promotion of better nutrition and improvement of health seem to be excluded from the purview of Indonesian government. Furthermore, self-sufficiency 
of rice is now being jeopardized and policy support for the development of oil pal production is less active than before.

Since the world has been changing rapidly, agriculture must change. First, since wage rate has been increasing in high-performing Asian countries, including Indonesia, laborsaving mechanical technology must be adopted. In order to facilitate mechanization, farm size expansion must take place (Otsuka 2013). Otherwise, agriculture, particularly farming of staple crops such as rice, will lose comparative advantage. Second, considering increasing demand for high-value agricultural products (HVPs), such as fresh fruit and vegetables and livestock products, for better nutrition and health, resources must be shifted from the production of staple crops to that of HVPs (Otsuka, Nakano, and Takahashi 2016). Otherwise, nutritional security cannot be assured. Third, the intensification of tree crop production, especially oil palm whose demand has been increasing and will continue to rise, must be promoted without sacrificing forest environment. Fourth, to promote the production of HVPs and encourage resource-based industrialization, development of agro-processing industries must be promoted by policy means (Otsuka and Ali 2020). It is important to note that HVPs must be either processed by agro-processing firms or graded and packed by pack houses before marketing, not to mention that commercial tree crops must be also processed. A 
critically important point is that, in general, firms in developing countries are poorly managed and, hence, their management must be improved to fully realize the potential of industrialization (Otsuka 2020).

The purposes of this article are, based on the literature review, to propose strategies (1) to maintain comparative advantage in rice farming, (2) to facilitate the shift of resources from rice production to the production of HVPs, and (3) to promote oil palm production without sacrificing environmental sustainability and social equity. A special attention will be paid to the roles of agro-industrialization led by the private sectors, public-sector extension activities for smallholders, and security of land rights for stimulating the production of oil palm.

The organization of this article is as follows. Section II discusses why farm size expansion and agricultural mechanization are critically important to maintain comparative advantage in rice farming in Indonesia. Section III provides strategy to develop HVP-oriented agriculture while paying special attention to the roles of contract farming, agricultural extension, and development of agro-processing industries. Section IV explores how to intensify smallholder oil palm production without accompanying extensification and forest degradation. Finally, conclusions and the policy implications are discussed in Section V. 


\section{NEEDE FOR FARM SIZE EXPANSION IN RICE FARMING}

\section{Changing Farm-Size and Productivity Relationship}

The relationship between fam size and productivity has been hotly debated for long time in the agricultural economics literature. The dominant view for developing countries is the inverse relationship between farm size and productivity (see, e.g., Lipton (2012)). As is clearly pointed out by Feder (1985) and Binswanger and Rosenzweig (1986), small farms are more productive than large farms because family labor is intensively applied on small farms in contrast to large farms, which rely on hired labor prone to shirking in the absence of close supervision. Hayami and Otsuka (1993) argue that labor markets in care intensive agricultural activities, such as land preparation, water management, and application of fertilizers, never work because of the difficulty in monitoring hired labor in spatially dispersed and ecologically diverse agricultural production environments. If land sale or tenancy markets function, however, to transfer cultivation rights from land-rich and labor-scarce large farms to land-poor and laborabundant small farms, the inverse relationship will be reduced or wiped out (Otsuka 2007). Therefore, the inverse relationship tends to be found in countries where land markets are suppressed by land reform laws, such as India. 
According to a recent meta-review of the literature by Delvaux, Riesgo, and Paloma (2020), the inverse relationship is widely observed between land productivity (crop yield or value of production per hectare) and farm size, whereas the relationship is less clear between profit per hectare and farm size. While profit is theoretically appropriate measure of production efficiency, its measurement is subject to errors because of the difficulty in imputing cost of unpaid family labor (Otsuka 2021). The fact that large landowners tend to lease out land to small and landless farmers indicates that the profitability of farming is higher on small than large farms. The two downward-sloping curves portrayed in Figure 1 illustrate the inverse relationship between yield or profit per hectare and farm size.

As Otsuka argues (2013), the advantage of small family farms tends to be eroded in economies where wage rate has been rising, because of the increasing labor cost. This is illustrated by flattened profit curve in Figure 1, which corresponds to sharper rise of labor cost on smaller farms. Furthermore, the advantage of using labor-intensive technology declines relative to labor-saving, capital-intensive mechanical technology, which is shown by higher profitability of capital-intensive technology than laborintensive technology after the wage growth. ${ }^{2}$ The advantage of capital-intensive

\footnotetext{
${ }^{2}$ For simplicity, both yield and profit curves with capital-intensive technology are assumed to be fixed. To be strict, the profit curve will shift downwards when wage rate increases, other things
} 
technology is pronounced on large farms as the scale economies arise with

mechanization, which entails significant fixed cost. As is indicated by the literature review of Otsuka (2021), the positive relationship between farm size and productivity prevails in high wage economies, such as Japan, and sometimes U-shaped relationship is observed in transition economies where both labor-intensive and capital-intensive technologies are adopted. Cross-country regression analysis by Otsuka, Liu, and Yamauchi (2013) confirms the weakening inverse relationship and the emergence of the positive relationship between farm size and productivity. A critically important observation is that self-sufficiency of grain production has declined drastically in Japan, South Korea, and Taiwan where small-scale farms have been preserved in the face of high and rising wages, indicating that these countries have been losing comparative advantage in the production of staple food crops (Otsuka, Liu, and Yamauchi 2016).

\section{Small and Shrinking Farm Size in Indonesia}

The average farm size in Indonesia is smaller than in most other Southeast Asian countries (Figure 2). Moreover, it has been declining over time. This is likely to be a serious problem because the advantage of small farms is bound to decrease in Indonesia where wage rate has been rising.

being the same. 
Indeed, Liu and Yamauchi (2014) found that large farms maintain their advantages in farming in this country. Moreover, Yamauchi (2016) found the emergence of the positive relationship between farm size and productivity, the expansion of large farms through land renting in outer islands, and their mechanization. These observations indicate the evolutionary changes in the farm size-productivity relationship in Indonesia from the inverse to the positive direction.

Such argument is supported by changes in farm size by major islands in Indonesia from 2003 to 2018 shown in Table 1. Farm size significantly increased in all four major islands for the 15 -year period. ${ }^{3}$ It is also important to note that the farm size is particularly tiny on Java island, which indicates that this island is not suited for mechanized rice production. Since significant farm size expansion and large-scale mechanization are unlikely to take place in this island, it ought to specialize in management intensive crop production, such as vegetables, and production of broilers and other agricultural products which are high-value products and do not require much farmland.

\section{Performance of Rice Sector in Indonesia}

Performance of rice sector in Indonesia measured by paddy yield is high among

\footnotetext{
${ }^{3}$ Note that farm size in 2003 might have been under-reported judging from dent in this year in Figure 2.
} 
Southeast Asian countries. As is shown in Figure 3, paddy yield in Indonesia increased significantly during the Green Revolution period in the 1970s and 1980s and it had been highest in Southeast Asia until the turn of the century. Paddy yield, however, became stagnant in the 2010s. Given the limited room for the expansion of paddy land, the total rice production was stagnant and will continue to do so coming years. Despite the stagnant rice production, rice self-sufficiency ratio has been close to unity in Indonesia according to Figure 4.

Rice self-sufficiency ratio is high and exceeds unity in Thailand, where farm size is large (see Figure 2), even though paddy yield is low (Figure 3). The selfsufficiency ratio is relatively high in Vietnam, even though farm size is small. Although not shown, farm size of rice farmers in Mekong Delta is relatively large and increasing from 1.0 hectare in 1996 to 1.4 hectares in 2009 (Estudillo and Otsuka 2016). In contrast, the self-sufficiency ratio is low and declining, and farm size is small in Malaysia. It seems that Malaysia is following the path taken by advanced countries in northeast Asia. These observations are consistent with my argument that a country loses comparative advantage in grain production in the face of increasing wage rate, if farm size remains small and, hence, large-scale mechanization is difficult or not effective in saving labor (Otsuka 2013). 
Indonesia maintained rice self-sufficiency without significantly relying on import importantly because of the import restriction. This is reflected in widened gap between world rice price, represented by $5 \%$ broken f.o.b. Thai rice, and domestic price, shown in Figure 5. Before the world food crisis year of 2008, domestic rice price was close to the world price, as the major purpose of the Indonesian rice policy was stabilization of domestic price as argued by Timmer (1993), Dawe (2001), and Dawe and Timmer (2012). The recent price gap of $100 \%$, however, is obviously excessive and detrimental to welfare of rice consumers and overall economic growth in Indonesia. ${ }^{4}$ Similar protectionist policy was also adopted by Malaysia and the Philippines in Southeast Asia (Hoang and Meyers 2015).

The price support has significant adverse impact on farm size expansion, because it tends to preserve inefficient small farms, according to the Japanese experience (Hayami 1988). If rice price is supported, paddy land prices as well as land rental fees become higher, which, in turn, leads to discouragement of land transfers from inefficient small farms to efficient large farms. As a result, farm size remains small, which tends to prevent large-scale mechanization to save labor cost. In consequence, comparative advantage in rice farming is lost, and to maintain the rice self-sufficiency further

\footnotetext{
${ }^{4}$ Fertilizer subsidy is also provided and Warr and Yusuf (2014) argue that this policy is more desirable than rice price support in terms of the impact on the social welfare.
} 
protection becomes necessary, resulting in vicious circle of the preservation of inefficient small farms and enhanced protection for them.

\section{Promot Farm Size Expansion}

The foremost and the most fundamental policy to promote farm size expansion is to abolish price support. Given exceedingly small current farm size, it is infeasible to achieve significant farm size expansion unless land prices and rental fees decline significantly. So far as land and machineries are complements, mechanization is promoted by farm size expanstion. The second policy is to shift rice production areas from Java island to outer islands, where farm size is larger and room for further farm size expansion is larger. This may be realized by promotion of more profitable products than rice in Java, such as vegetables. Since such products must be marketed while products are fresh, Java island has advantage in the production where access to urban markets is favorable. The third policy is to facilitate land renting by strengthening land rights of owners. Finally, large-scale mechanization should be promoted by encouraging enlargement of plot size and consolidation of scattered land holdings. Unless significant farm size expansion and large-scale mechanization take place, production cost of rice farming will continue to rise in Indonesia, thereby resulting in large import of rice and reduced rice self-sufficiency or the expansion of costly protectionist policies for rice 
farming.

\section{PROMOTION OF HIGH-VALUE PRODUCTS}

\section{Neglect of HVPs}

Responding to income growth and urbanization, the demand for HVPs has been rapidly increasing for better nutrition and health in developing countries. Yet, in general, the supply of HVPs fails to keep pace with their increasing demand, which results in high relative price of HVPs (Headey and Masters 2021). Indonesia does not seem to be an exception. According to Table 2, harvested areas of fruit and vegetables account for tiny share of total agricultural area and they increased only slightly from 2003 to $2018 .^{5}$

Observing slow growth of production of HVPs, Reardon et al. (2015, p. 372) argue that "If Indonesian farmers cannot access the supply chains that meet domestic consumer demand, foreign farmers will." As a matter of fact, Indonesia is a large net importer of vegetables, along with Malaysia, and the import of fruit and vegetables has been rising (Figure 6). ${ }^{6}$

The increasing production of HVPs has been assisted by the "supermarket

\footnotetext{
${ }^{5}$ Note that harvested area of fruit covers all kinds of fruit production areas, whereas that of vegetables includes only major vegetable items (i.e., shallots, chili, potatoes, cabbages, Chinese cabbages, and tomato), so that its harvested area is underestimated.

${ }^{6}$ Indonesia is net exporter of fruit, so that net import of vegetables is larger than that of fruit and vegetables combined.
} 
revolution" in many parts of developing countries (Reardon and Minten 2021). Yet, the impact of emerging modern food value chain on the production of smallholders in Indonesia is limited (Minot et al. 2015). Toiba, Umberger, and Minot (2015) point out that modern retail outlets led by supermarkets do not contribute to consumption of healthy foods. Although Hernández et al. (2015) point out that the West Java has been transformed from major rice bowl to major vegetable basket, such transformation does not seem to be widespread compared with many other developing countries in Asia. There is a clear need for expanding the production of HVPs in this country for improved health and nutrition.

\section{Role of Contract Farming}

In general, HVPs are improved products, input intensive, and new to farmers.

Therefore, markets of new inputs, such as new improved seeds and safe pesticides, are either missing or imperfect, system of disseminating new technology and management knowledge is weak, and, as is often the case, credit market is not working to support the purchase of new inputs. Furthermore, the quality and safety of HVPs cannot be easily verified by visual observation of consumers, so that inefficient marketing of differentiated products can be potentially a major constraint. Another issue is price risk, as prices of HVPs tend to fluctuate widely and unexpectedly. Therefore, risk averse 
smallholders may be reluctant to engage in the production of HVPs in the absence of insurance programs. Contract farming emerges to deal with these market failures. ${ }^{7}$

Roughly speaking, there are two types of contract farming. In the case of "production contract," contractor, who is often supermarket or agro-processor, provides inputs on credit and technological support in return for the delivery of certain quantity and quality of products at predetermined time in accordance with the predetermined price or pricing formula. The contractor closely supervises the production to ensure the high quality of products and tries to prevent the use of provided inputs for other purposes and "sideselling" of products to marketing agents, not the contractor. In the case of the "marketing contract," contractor specifies inputs and provides advice, while delegating most production decisions to farmers. Thus, famers have more autonomy in decision making in the marketing contract than the production contract. In both cases, contractor undertakes marketing of HVPs. Thus, the length of marketing channels is short, unlike traditional marketing system in which village collectors, township traders, and urban traders are connected with one another, and they connect farmers with urban markets (Hayami and Kawagoe 1993).

In Indonesia the production contract is adopted for the production of hybrid

\footnotetext{
7 Otsuka, Nakano, and Takahashi (2016) conducted a comprehensive literature review, whereas Otsuka and Zhang (2021) carried out updated review.
} 
seed corn, seed rice, and broilers (Simmons, Winters, and Patrick 2005; Winters, Simmons, and Patrick 2005) and specialty coffee (Vicol et al. 2018). ${ }^{8}$ These are highquality products subject to the quality uncertainty and contractors are generally foreign agro-dealers and agro-processors, who are keen about the product quality. On the other hand, the marketing contract seems to be practiced between traders or wholesalers and farmers in the production of tomato (Hernández et al. 2015), shrimp (Yi and Reardon 2015), chili (Sahara et al. 2015), and potato (Umberger et al. 2015). In these marketing contracts, traders and wholesalers assemble, grade, sort out, and pack contracted products, occasionally provide technical support, and sell the products to supermarkets and restaurants in urban areas. ${ }^{9}$ Although how common contract farming is in Indonesia is unclear, there seems to be little doubt that contract farming contributes, at least potentially, to expanded production of HVPs in this country.

\section{Shortfall of Contract Farming}

Since contract farming introduces new seeds, products, and production methods, it undoubtedly contributes to modernization of agriculture in developing countries. Thus, World Bank (2007) strongly advocates contract farming for introducing HVPs in

\footnotetext{
${ }^{8}$ Contract farming is also practiced for oil palm production and I will discuss about it separately in Section IV.

9 To my of knowledge, such contract farming led by traders and wholesalers is not practiced in other countries.
} 
agriculture in developing countries. However, whether farmers are significantly made better-off by contract farming is widely debated by numerous empirical studies. Ton et al. (2018) point out through meta-analysis that assessment of the income effect of contract farming is upwardly biased due to mechanically excluding contract farming arrangements that failed and due to the tendency that primarily successful cases of contract farming are reported in published articles. Overall, they are skeptical of large effects of contract farming on farmers' income. Summarizing the empirical literature, Otsuka, Nakano, and Takahashi (2016) argue that farmers would not receive large benefits from production contract because they passively accept inputs and production instructions without undertaking any major management and marketing decisions. This means that farmers do not receive income accrued to superior decisions. According to the updated review of the literature by Otsuka and Zhang (2021), such conclusion seems to be also supported by recent studies.

In order to make farmers significantly better-off, they must be trained to acquire the knowledge of improved technology, cultivation methods, and marketing so as to transform themselves from subsistence farmers into entrepreneurs, who make critical decisions (Otsuka and Fan 2021). Unless farmers are able to make appropriate decisions in dynamic setting where technology, the availability of inputs, and the 
structure of product demand are changing, they can hardly receive substantial income gains accrued to superior entrepreneurial decisions.

The literature on contract farming seldom distinguishes between the production and marketing contracts. Probably, however, the most existing studies deal with the production contracts judging from the description of contracts. In this contract, the contractor undertakes intensive monitoring of contracted farmers to ensure the production of high-quality products. In the case of marketing contracts, however, farmers' decision-making autonomy is largely maintained and the contractor provides only broad production instructions. Thus, it is obvious that farmers' knowledge to produce high-quality products will be limited under the marketing contract. If so, it is unconceivable that farmers are significantly made better-off by the introduction of the marketing contract.

\section{Strengthen Extension and Support Agro-processing Sector}

There are two fundamental requirements to improve efficiency of farming and farmers' well-being by the introduction of the contract farming (Otsuka and Ali 2020). The first one is to strengthen extension systems for HVPs. Since many HVPs are new to farmers, dissemination of appropriate knowledge of technology, cultivation methods, and marketing to farmers or farmers' groups is needed. This may be done by the production 
contract to some extent, but in this case entrepreneurial profits will accrue to

contractors, not to farmers. Thus, famers' income is unlikely to increase significantly.

Strengthening extension system for HVPs is not easy, however, because of the lack of researchers and extension workers specialized on HVPs. Therefore, a major reform of research and extension systems is required.

The second requirement is to nurture agro-processing firms by investing in human capital of entrepreneurs (or managers and owners of local firms). By now it is widely recognized that a major missing factor for the development of manufacturing firms in developing countries is managerial ability, which is vitally needed for innovations (e.g., Bloom and van Reenen 2010; Sonobe and Otsuka 2011; Otsuka, Jin, and Sonobe 2018; McKenzie 2020). Because of the imitation by rival firms, social rate of return to investing in human capital to acquire new production and management knowledge is higher than private rate of return. As a result, the amount of human capital investment tends to fall short of the social optimum. Consequently, manufacturing firms in developing countries are generally poorly managed and not sufficiently innovative. Therefore, in order to develop agro-processing sectors, the government ought to organize the training program for local agro-processors so as to stimulate the introduction of new technology and management methods (Otsuka 2020). Otherwise, 
the development of agricultural sectors producing HVPs will be constrained by the lack of productive agro-processors. It must be pointed out at this point that fresh fruit and vegetables are shipped to supermarkets in urban areas after washing, fumigating, grading, and packing at partly mechanized pack houses by employing a large number of workers and, as such activities at pack houses should considered as important industrial activities in rural areas.

\section{INTENSIFICATION OF OIL PALM PRODUCTION}

Indonesia produces a range of tree products including rubber, coffee, cocoa, and oil palm. Among them, oil palm is most important in terms of harvested area, which increased 2.5 times from 2003 to 2018 (see numbers in parentheses under tree crops in Table 2). Moreover, so many studies on the oil palm production have been published, which provide useful information. Thus, this section focuses on the oil palm production.

\section{Plantation vs. Smallholder Farms}

Many tree products as well as some tropical fruits and sugarcane are produced by plantation. Oil palm in Indonesia was produced primarily by the state-owned plantations before 1995 when state began handing over the functions of plantations to the private sectors (Pramudya and Hospes 2017). Since then, state interventions in the oil palm 
sector declined significantly. State obliged the private plantations to offer contract farming to smallholders (Cahyadi and Waibel 2016; Euler et al. 2016b; Gatto, Wollni, and Qaim 2015; Gatto et al. 2017; Krishna et al. 2017). Gradually the production by smallholders increased and almost caught up with the private plantations in terms of planted area by the mid-2010s. An important observation is that the number of independent smallholders who have never had contracts with the plantations increased dramatically and increased their operation size, thereby far surpassing the number of contracted smallholders, whose number and operation size remained largely unchanged since the end of the 1990s (Euler et al. 2016b). Then, the question arises as to whether the plantation is more efficient than smallholders in the production of oil palm.

Binswanger and Rosenzweig (1986) argue that the plantation has an advantage in processing, which is subject to scale economies, because many plantation crops must be processed immediately after harvesting and because the plantation can coordinate agricultural production activities such that processing facilities are operated with full capacity. They also argue, however, that plantation has disadvantage compared with smallholders or family farms in agricultural production because of high monitoring cost of hired workers. The logic behind this argument is the same as for the inverse relationship between farm size and productivity except for the fact that monitoring is 
less costly for the mono-cultural production by plantations. Hayami (2001) concurs with Binswanger and Rosenzweig that smallholder production is more efficient that the production by the plantation. Alluding to the case of pineapple and sugarcane production in Thailand and the Philippines, he pointed out that the production by smallholders under contract farming in Thailand grew much faster than that by the plantations in the Philippines.

Supporting the preceding arguments, Byerlee (2014, p. 574) argues that "Although the production of all these (tea, rubber, oil palm, and cassava) was initiated in the colonial period on large plantations, over the course of the $20^{\text {th }}$ century. Most transited to smallholder system....., smallholders overwhelmingly dominated perennial crop exports, except possibly oil palm." He also pointed out that the structure of oil palm production has been shifting in favor of smallholders in Indonesia. The plantation might have been more efficient than smallholders in the earlier period when huge pioneering costs of investing in clearance of fields and transportation and communication infrastructure were needed. Once infrastructure is developed, the advantage of the plantation is likely to be lost. The oil palm production, however, is highly capital intensive (Krishna et al. 2017) and, hence, large plantations which have good access to finance might have had some advantage over smallholders. The share of 
oil palm production by plantation, however, has been gradually declining to nearly onehalf, as smallholders expanded their production. ${ }^{10}$ Once plantations are established, it is difficult to resolve them because land sales markets seldom function well. Yet, it seems clear that oil palm production by smallholders is more efficient than plantations in Indonesia.

\section{Contract farming and Smallholder Oil Palm Production}

The Indonesian government obliged private plantations to assist a certain number of smallholder farmers with the establishment of oil palm smallholdings and to provide inputs, credit, and technical assistance (Cahyadi and Waibel 2016; Euler et al. 2016b;

Gatto, Wollni, and Qaim 2015). The contract farming also provides various supports for the establishment of oil palm fields, which was helpful for smallholders because it takes several years for planted trees to bear fruits. Furthermore, the contract farming (or the production contract) helps reduce coordination cost for the contractor compared with procurement of oil palm fruits through market transactions.

It is usually group of farmers, rather than individual farmers, who made contracts with private plantations. This will reduce transaction cost for plantations and such groupbased contractual relationship is wisely observed in developing countries (Otsuka,

\footnotetext{
10 Although I could not find concrete evidence, I suspect that some parts of plantations are rented
} out to smallholders or cultivated by smallholders under contract. 
Nakano, and Takahashi 2016). To the extent that community ties are loose, however, the transaction cost may not be saved significantly by the group-based contracts. Also elite capture may occur in the case of such contracts (Vicol et al. 2018).

There are several studies which found positive effect of contract farming on smallholders' well-being (Gatto et al. 2017; Krishna et al. 2017; Santika et al. 2019), even though there are studies which did not find such effect (Cahyadi and Waibel 2016; Santika et al. 2019). ${ }^{11}$ There seems to be no question that contract farming, particularly the production contract type, triggered the development of smallholder oil palm production.

\section{Expansion of Independent Smallholders' Production}

The oil palm production by independent smallholders grew much faster than that by contracted smallholders (Euler et al. 2016b; Gatto et al. 2017). According to Euler et al. (2016b) and Gatto et al. (2017), about 75\% of their sample smallholder households growing oil palm in Sumatra were independent ones in the 2010s, even though their share was only $5 \%$ in the early 1990 s. It is somewhat puzzling to observe that the yield of the former is much lower than the latter (Euler et al. 2016a). Pramudya and Hospes

${ }^{11}$ Santika et al. (2019) found the positive effect in market-oriented villages but the negative effect in subsistence-based villages. Considering that contract farming is chosen by farmers, it is not clear to me why it had negative welfare effect. 
(2017, pp. 68-69) report that independent smallholders started their plantation with their own money..... They used seeds from fallen fruit or brought uncertified seeds and relied on knowledge from friends or family who had plantation or had previously worked from an estate company." Gatto et al. (2017) also found that independent growers learned from contracted growers. Euler et al. (2016a) point out that independent smallholders apply only a little amount of fertilizer, the mortality of their plants is low, and harvesting cycle is too long. In short, their management is inefficient.

The question immediately arises why inefficient smallholders have expanded their oil palm production. Gatto et al. (2017) argue that credit and input markets have developed and access to palm oil mills has improved, which stimulated the production by independent smallholders. If this is true, advantage of contract farming will decrease over time. Another important factor is secure land rights: independent smallholders are often transmigrants who received land titles and converted rubber fields and fallow land to oil palm fields (Gatto et al. 2015). Since land title can be used as collateral, its holders have good access to credit, which leads to higher yields and profitability (Krishna et al. 2017).

In my view, the absence of quality uncertainty about produced oil palm fruit allowed the increased production by independent smallholders. As I argued before, one 
of the advantages of contract farming is that the quality uncertainty is reduced by agro-

dealers and supermarkets. In the case of palm oil, the quality difference is minimum.

This implies that the advantage of contract farming over arms-length marketing

transaction is low. Partly because of this and partly because of the development of input, output, and credit markets, the advantage of contract farming, if any, must have become much smaller than before. These considerations explain why independent smallholders dominate in oil palm production over contracted smallholders.

\section{Support Independent Smallholders by Extension and Land Titling}

Somewhat similar to the recommendations for the promotion of HVPs, there are three fundamental requirements to improve efficiency of oil palm production. The first one is to strengthen extension systems for independent smallholders (Euler et al. 2016a). As was mentioned earlier, they are not efficient producers, even though their farming is more efficient than farming under the production contract, not to mention the production by private plantations. Obviously improved production methods must be disseminated to them for enhancing the efficiency of their production. In this connection, it is instructive to learn the experience of cocoa sector development in Sulawesi in which the government, private grinding firms, and NGOs provide training, conduct experimentation, and exhibit demonstration (Neilson and McKenzie 2016). 
As in the case of HVPs, the second requirement is to train managers and owners of palm oil mills by investing in their human capital. It is a mistake to assume that private enterprises are managed as efficiently as they ought to be. Bloom and van Reenen (2010), Sonobe and Otsuka (2011), Otsuka, Jin, and Sonobe (2018), and McKenzie (2020), among others, demonstrate that management training is conducive to the improvement of management efficiency of manufacturing enterprises in developing countries.

Third requirement is the establishment of secure land rights. It is fundamental condition for sustainable management of natural resources, including tree crops (Otsuka and Place 2001; Place, Meinzen-Dick, and Ghebru 2021). If land rights are insecure, incentives to invest in tree management will be thwarted. Land titling, however, may not lead to secure land rights, if collective family ownership of land prevails because family members have to choose an individual owner of their collective land under the land titling program. Fortunately in Sumatra where oil palm is most actively grown, ownership of family land has been individualized even in native communities (Suyanto, Tomich, and Otsuka 2001). Therefore, I support the argument of Gatto, Wollni, and Qaim (2015), Krishna et al. (2017) and Pramudya and Hospes 2017) that land titles should be granted to independent smallholders for intensification of palm oil 
production. $^{12}$

\section{CONCLUDING REMARKS}

Indonesian agriculture is at the cross-roads: (1) it may continue to lose comparative advantage in rice farming by protecting smallholders or restore competitiveness of rice farming by facilitating farm size expansion and mechanization; (2) it may continue to neglect the production of HVPs or begin the support for the expansion of their production for the benefit of both producers and consumers; (3) it may continue inefficient production of palm oil by plantations and contracted smallholders or strengthen efficiency of production of independent oil palm growers; and (4) it may continue to endure lack of nonfarm employment opportunities in rural areas or create such opportunities by vitalizing agro-processing industries, including pack-house activities.

Corresponding to the above issues, I would like to propose the following strategies for transforming Indonesian agriculture. First, the government should support farm size expansion and mechanization in rice farming by abolishing price protections

\footnotetext{
12 Although I did not discuss about the concern with extensification of oil palm production at the sacrifice of forestland, it is certainly desirable to regulate the extensification from the global environmental point of view.
} 
and supporting rice production in outer islands where the room for farm size expansion is larger than in Java. Second, the government must strengthen public-sector extension for HVPs and oil palm production by smallholders. Third, the government should grant land title to independent oil palm growing smallholders for sustainable and efficient management of oil palm production. Finally, the government should promote rural industrialization by investing in human capital of agro-processors and managers of pack houses and palm oil mills. Clearly major shifts in agricultural policies are called for to achieve efficient, equitable, and sustainable growth of agriculture and rural areas in Indonesia. 


\section{References}

Binswanger, Hans P., and Mark R. Rosenzweig. 1986. "Behavioral and Material Determinants of Production Relations in Agriculture." Journal of Development Studies 22(3): 503-39.

Bloom, Nicholas, and John Van Reenen. 2010. "Why Do Management Practices Differ across Firms and Countries?” Journal of Economic Perspectives 24(1): 203-24.

Byerlee, Derek. 2014. "The Fall and Rise again of Plantations in Tropical Asia: History Repeated?" Land 3(3): 574-97.

Cahyadi, Eko Rudday, and Hermann Waibel. 2016. "Contract Farming and Vulnerability to Poverty and Oil Palm Smallholders in Indonesia." Journal of Development Studies 52(5): 681-95.

Dawe, David. 2001. "How Far Down the Path to Free Trade? The Importance of Rice Price Stabilization in Developing Asia.” Food Policy 26(2): 163-75.

Dawe, David, and Peter C. Timmer. 2012. "Why Stable Food Prices Are a Good Thing: Lessons from Stabilizing Rice Prices." Global Food Security 1: 127-33.

Estudillo, Jonna P., and Keijiro Otsuka. 2016. Moving out of Poverty: An Inquiry into the Inclusive Growth in Asia. Oxford: Routledge.

Euler, Michael, Munir P. Hoffmann, Zakky Fathoni, and Stefan Schwarze. 2016a. "Exploring Yield Gaps in Smallholder Oil Palm Production Systems in Eastern Sumatra, Indonesia." Agricultural Systems 146: 111-19.

Euler, Michael, Stefan Schwarze, Hermanto Siregar, and Matin Qaim. 2016b. "Oil Palm Expansion among Smallholder Farmers in Sumatra, Indonesia." Journal of Agricultural Economics 67(3): 658-76.

Feder, Gershon. 1985. "The Relations between Farm Size and Farm Productivity: The Role of Family Labor, Supervision, and Credit Constraints.” Journal of Development Economics 18(2-3): 297-313.

Food and Agriculture Organization of the United Nations, various years. Food Price Monitoring and Analysis. 
Food and Agriculture Organization of the United Nations, various years. World Census of Agriculture.

Garzon Delvaux, Pedro A., Laura Riesgo, and Sergio G. Paloma. 2020. “Are Small Farms More Performant than Larger Ones in Developing Countries?” Science Advances 6(41): eabb8235.

Gatto, Marcel, Meike Wollni, Rosyani Asnawi, and Matin Qaim. 2017. “Oil Palm Boom, Contract Farming, and Rural Development.” World Development 95: 127-40.

Gatto, Marcel, Meike Wollni, and Matin Qaim. 2015. "Oil Palm Boom and Land Use Dynamics in Indonesia: The Role of Policies and Socioeconomic Factors." Land Use Policy 46: 292-303.

Hayami, Yujiro. 1988. Japanese Agriculture under Siege: The Political Economy of Agricultural Policies. London: Macmillan.

Hayami, Yujiro. 2001. "Ecology, History, and Development: A Perspective from Rural Southeast Asia.” World Bank Research Observer 16(2): 169-98.

Hayami, Yujiro, and Toshihiko Kawagoe. 1993. The Agrarian Origin of Commerce and Industry: A Study of Peasant Marketing in Indonesia. New York, NY: St Martin's Press. Hayami, Yujiro, and Keijiro Otsuka. 1993. The Economics of Contract Choice: An Agrarian Perspective. Oxford: Clarendon Press.

Headey, Derek, and William A. Masters. 2021. “Agriculture and Undernutrition.” In Agricultural Development: New Perspectives in a Changing World, edited by Keijiro Otsuka and Shenggen Fan, 321-58. Washington, DC: International Food Policy Research Institute.

Hernández, Ricardo, Thomas Reardon, Ronnie Natawidjaja, and Shobha Shetty. 2015. "Tomato Farmers and Modernizing Value Chains in Indonesia." Bulletin of Indonesian Economic Studies 51(3): 425-44.

Hoang, Hoa K., and William H. Meyers. 2015. "Price Stabilization and Impacts of Trade Liberalization in the Southeast Asian Rice Market." Food Policy 57: 26-39. Indonesia, Bureau of Statistics (BPS). 2003a and 2013a. Agricultural Census 2003. Indonesia, Bureau of Statistics (BPS). 2003b and 2018b. Statistics Indonesia. 
Indonesia, Bureau of Statistics (BPS). 2018a. The Results of Inter-census Agriculture Survey 2018.

Krishna, Vijesh, Michael Euler, Hermanto Siregar, and Matin Qaim. 2017. "Differential Livelihood Impacts of Oil Palm Expansion in Indonesia.” Agricultural Economics 48(5): 639-53.

Lipton, Michael. 2012. Land Reform in Developing Countries: Property Rights and Property Wrongs. London, UK: Routledge.

Liu, Yanyan, and Futoshi Yamauchi. 2014. "Population Density, Migration, and the Returns to Human Capital and Land.” Food Policy 48: 182-93.

McKenzie, David. 2020. "Small Business Training to Improve Management Practices in Developing Countries: Reassessing the Evidence for 'Training Doesn't Work'." Policy Research Working Paper 9408. Washington, DC: World Bank.

Minot, Nicholas, Randy Stringer, Wendy J. Umberger, and Wahida Maghraby. 2015. "Urban Shopping Patterns in Indonesia and Their Implications for Small Farmers." Bulletin of Indonesian Economic Studies 51(3): 375-88.

Neilson, Jeffrey, Angga Dwiartama, Noels Fold, and Dikdik Permadi. 2020. "ResourceBased Industrial Policy in an Era of Global Production Networks: Strategic Coupling in the Indonesian Cocoa Sector.” World Development 135: 105045.

Neilson, Jeffrey, and Fiona McKenzie. 2016. "Business-oriented Outreach Progrmmes for Sustainable Cocoa Production in Indonesia: An Institutional Innovation.” In Innovative Markets for Sustainable Agriculture: How Innovations in Market Institutions Encourage Sustainable Agriculture in Developing Countries, edited by A. Loconto, S. Poisot, and P. Santacoloma, 17-35. Rome: Food and Agriculture Organization of the United Nations.

Otsuka, Keijiro. 2007. "Efficiency and Equity Effects of Land Markets." In Handbook of Agricultural Economics, Volume III, edited by Robert E. Evenson and Prabhu Pingali, 2671-701. Amsterdam: Elsevier.

Otsuka, Keijiro. 2013. "Food Insecurity, Income Inequality, and the Changing Comparative Advantage in World Agriculture.” Agricultural Economics 44(S1): 7-11.

Otsuka, Keijiro. 2020. "Strategy for Cluster-Based Industrial Development in Developing Countries.” Graduate School of Economics Discussion Paper No. 2019, 
2020. Kobe: Kobe University.

Otsuka, Keijiro. 2021. "Changing Relationship between Farm Size and Productivity and Its Implications for Philippine Agriculture.” Graduate School of Economics Discussion Paper No. 2102, Kobe: Kobe University.

Otsuka, Keijiro, and Mubarik Ali. 2020. "Strategy for the Development of Agro-based Clusters.” World Development Perspectives 20: 100257.

Otsuka, Keijiro, and Shenggen Fan (eds.). 2021. Agricultural Development: New Perspectives in a Changing World. Washington, DC: International Food Policy Research Institute.

Otsuka, Keijiro, Kimiaki Jin, and Tetsushi Sonobe. 2018. Applying the Kaizen in Africa: A New Avenue for Industrial Development. New York: Palgrave Macmillan.

Otsuka, Keijiro, Yanyan Liu, and Futoshi Yamauchi. 2013. "Factor Endowments, Wage Growth, Changing Food Self-Sufficiency: Evidence from Country-Level Panel Data." American Journal of Agricultural Economics 95(5): 1252-58.

Otsuka, Keijiro, Yanyan Liu, and Futoshi Yamauchi. 2016. "The Future of Small Farms in Asia." Development Policy Review 34(3): 441-61.

Otsuka, Keijiro, Yuko Nakano, and Kazushi Takahashi. 2016. "Contract Farming in Developed and Developing Countries." Annual Review of Resource Economics 8: 35376

Otsuka, Keijiro, and Frank Place. 2001. Land Tenure and Natural Resource Management: A Comparative Study of Agrarian Communities in Asia and Africa. Baltimore, MD: Johns Hopkins University Press

Otsuka, Keijiro, and Xiaobo Zhang. 2021. "Transformation of the Rural Economy.” In Agricultural Development: New Perspectives in a Changing World, edited by Keijiro Otsuka and Shenggen Fan, 359-95. Washington, DC: International Food Policy Research Institute.

Place, Frank, Ruth Meinzen-Dick, and Hosaena Ghebru. 2021. "Natural Resource Management and Resource Rights for Agriculture." In Agricultural Development: New Perspectives in a Changing World, edited by Keijiro Otsuka, and Shenggen Fan, 595- 
625. Washington, DC: International Food Policy Research Institute.

Pramudya, Eusebius Pantja, and Otto Hospes. 2017. "Governing the Palm-Oil Sector through Finance: The Challenging Roles of the Indonesian State." Bulletin of Indonesian Economic Studies 53(1): 57-82.

Reardon, Thomas, and Bart Minten. 2021. "Food Value Chain Transformation in Developing Regions." In Agricultural Development: New Perspectives in a Changing World, edited by Keijiro Otsuka, and Shenggen Fan, 397-437. Washington, DC: International Food Policy Research Institute.

Reardon, Thomas, Randy Stringer, C. Peter Timmer, Nicholas Minot, and Arief Daryanto. 2015. "Transformation of the Indonesian Agrifood System and the Future beyond Rice: A Special Issue.” Bulletin of Indonesian Economic Studies 51(3): 369-73.

Sahara, Sahara, Nicholas Minot, Randy Stringer, and Wendy J. Umbeger. 2015. “Determinants and Effects of Small Chili Famers' Participation in Supermarket Channels in Indonesia.” Bulletin of Indonesian Economic Studies 51(3): 445-60.

Santika, Truly, Kerrie A.Wilson, Sugeng Budiharta, Elizabeth A. Law, Tun Min Poh, MarcAncrenaz, Matthew J. Struebig, Erik Meijaard. 2019. "Does Oil Palm Agriculture Help Alleviate Poverty? A Multidimensional Counterfactual Assessment of Oil Palm Development in Indonesia." World Development 120: 105-17.

Simmons, Phil, Paul Winters, and Ian Patrick. 2005. "An Analysis of Contract Farming in East Java, Bali, and Lombok.” Agricultural Economics 33(S3): 513-25.

Sonobe, Tetsushi, and Keijiro Otsuka. 2011. Cluster-Based Industrial Development: A Comparative Study of Asia and Africa. Hampshire, UK: Palgrave Macmillan.

Suyanto, S., Thomas P. Tomich, and Keijiro Otsuka. 2001. "Agroforestry Management in Sumatra." In Land Tenure and Natural Resource Management: A Comparative Study of Agrarian Communities in Asia and Africa, edited by Keijiro Otsuka and Frank Place, 97-143. Baltimore, MD: Johns Hopkins University Press.

Timmer, C. Peter. 1993. "Rural Bias in the East and South-east Asian Rice Economy: Indonesia in Comparative Perspective.” Journal of Development Studies 29(4): 149-76.

Toiba, Hery, Wendy J. Umberger, and Nicholas Minot. 2015. “Diet Transition and 
Supermarkets Shopping Behaviour: Is There a Link?” Bulletin of Indonesian Economic Studies 51(3): 389-403.

Ton, Giel, Wyste Vellema, Sam Desiere, Sophia Weitushat, and Marijke D’Haese. 2018. "Contract Farming for Improving Smallholder Incomes: What Can We Learn from Effectiveness Studies.” World Development, 104: 46-64.

Umberger, Wendy J., Thomas Reardon, Randy Stringer, and Simone Mueller Loose. 2015. "Market Channel Choices of Indonesian Potato Farmers: A Best-Worst Scaling Experiment." Bulletin of Indonesian Economic Studies 51(3): 461-77.

Vicol, Mark, Jeffrey Neilson, Diany Faila Sophia Hartatri, and Peter Cooper. 2018. "Upgrading for Whom? Relationship Coffee, Value Chain Interventions and Rural Development in Indonesia." World Development 110: 26-37.

Warr, Peter, and Arief Anshory Yusuf. 2014. "Fertilizer Subsidies and Food Selfsufficiency in Indonesia." Agricultural Economics 45(5): 571-88.

Winters, Paul, Phil Simmons, and Ian Patrick. 2005. "Evaluation of a Hybrid Seed Contract between Smallholders and a Multinational Company in East Java, Indonesia." Journal of Development Studies 41(1): 62-89.

World Bank. 2007. World Development Report 2008: Agriculture for Development. Washington, DC: World Bank.

Yamauchi, Futoshi. 2016. "Rising Real Wages, Mechanization, and Growing Advantage of Larger Farms: Evidence from Indonesia.” Food Policy 58: 62-69.

Yi, Dale, and Thomas Reardon. 2015. "Allocative Efficiency of Agrifood Traders: Shrimp Traders in Indonesia.” Bulletin of Indonesian Economic Studies 51: 405-23. 
Table 1. Average farm size (ha) in major islands in Indonesia in 2003 and 2018

\begin{tabular}{lrrrrrrrr}
\hline & \multicolumn{3}{c}{2003} & & \multicolumn{3}{c}{2018} \\
\cline { 2 - 3 } \cline { 7 - 8 } & Paddy & Upland & Total & & Paddy & Upland & \multicolumn{1}{c}{ Total } \\
\hline Java & 0.08 & 0.09 & 0.17 & & 0.18 & 0.16 & 0.33 \\
Sumatra & 0.15 & 0.58 & 0.73 & & 0.15 & 1.05 & 1.20 \\
Kalimantan & 0.20 & 0.69 & 0.88 & & 0.27 & 1.43 & 1.69 \\
Sulawesi & 0.15 & 0.55 & 0.70 & & 0.27 & 0.75 & 1.02 \\
Indonesia & 0.10 & 0.25 & 0.35 & & 0.18 & & 0.55 & 0.73 \\
\hline
\end{tabular}

Source: Bureau of Statistics (2003a, 2018a) 
Table 2. Cropping patterns in terms of planted area of rice and tree crops and harvested areas of fruit and vegetable (million hectares) in major islands in 2003 and 2018

\begin{tabular}{|c|c|c|c|c|c|c|c|c|c|c|}
\hline & \multicolumn{5}{|c|}{2003} & \multicolumn{5}{|c|}{2018} \\
\hline & Paddy & Tree crops ${ }^{\mathrm{a}}$ & Fruit ${ }^{\mathrm{b}}$ & Vegetables $^{\mathrm{c}}$ & Total $^{\mathrm{d}}$ & Paddy & Tree crops ${ }^{\mathrm{a}}$ & Fruit ${ }^{\mathrm{b}}$ & Vegetables $^{\mathrm{c}}$ & Total $^{\mathrm{d}}$ \\
\hline \multirow[t]{2}{*}{ Java } & 3.3 & 0.4 & 0.3 & 0.3 & 4.3 & 3.5 & 0.5 & 0.5 & 0.4 & 4.9 \\
\hline & & $(0.0)^{\mathrm{f}}$ & & & & & $(0.0)^{\mathrm{f}}$ & & & \\
\hline \multirow[t]{2}{*}{ Sumatra } & 2.3 & 7.3 & 0.2 & 0.1 & 9.9 & 1.5 & 11.8 & 0.1 & 0.2 & 13.6 \\
\hline & & $(4.0)^{\mathrm{f}}$ & & & & & $(8.0)^{\mathrm{f}}$ & & & \\
\hline \multirow[t]{2}{*}{ Kalimantan } & 0.9 & 1.9 & 0.0 & 0.0 & 2.8 & 0.7 & 6.6 & 0.1 & 0.0 & 7.4 \\
\hline & & $(1.0)^{\mathrm{f}}$ & & & & & $(5.6)^{f}$ & & & \\
\hline \multirow[t]{2}{*}{ Sulawesi } & 0.9 & 0.9 & 0.1 & 0.0 & 1.9 & 1.0 & 1.5 & 0.1 & 0.1 & 2.7 \\
\hline & & $(0.1)^{\mathrm{f}}$ & & & & & $(0.4)^{\mathrm{f}}$ & & & \\
\hline \multirow[t]{2}{*}{ Indonesia ${ }^{\mathrm{e}}$} & 7.9 & 10.8 & 0.8 & 0.5 & 20.0 & 7.1 & 20.9 & 1.1 & 0.7 & 29.8 \\
\hline & & $(5.6)^{\mathrm{f}}$ & & & & & $(14.3)^{\mathrm{f}}$ & & & \\
\hline
\end{tabular}

a. Tree crops include oil palm, rubber, cocoa, and coffee.

b. Fruit includes all kinds of fruit trees.

c. Vegetables include shallots, chili, potatoes, cabbages, Chinese cabbages, and tomatoes.

d. Total is the sum of paddy, tree crop, fruit, and vegetable areas.

e. The data refer to Indonesia as a whole, not the sum of areas in four major islands.

f. Oil palm area.

Source: Bureau of Statistics (2003b, 2018b). 


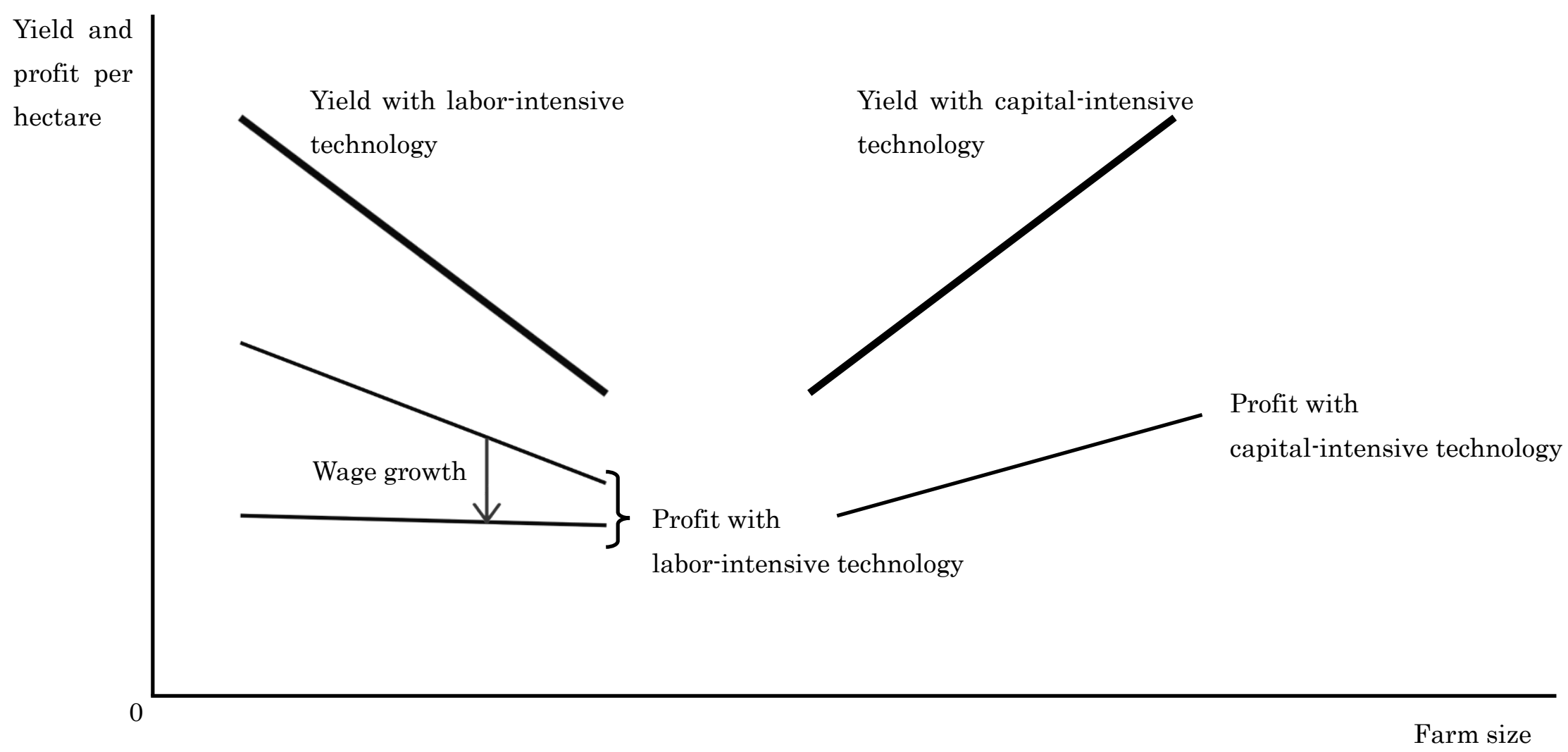

Figure 1. Conceptual relationships between farm size and productivity 


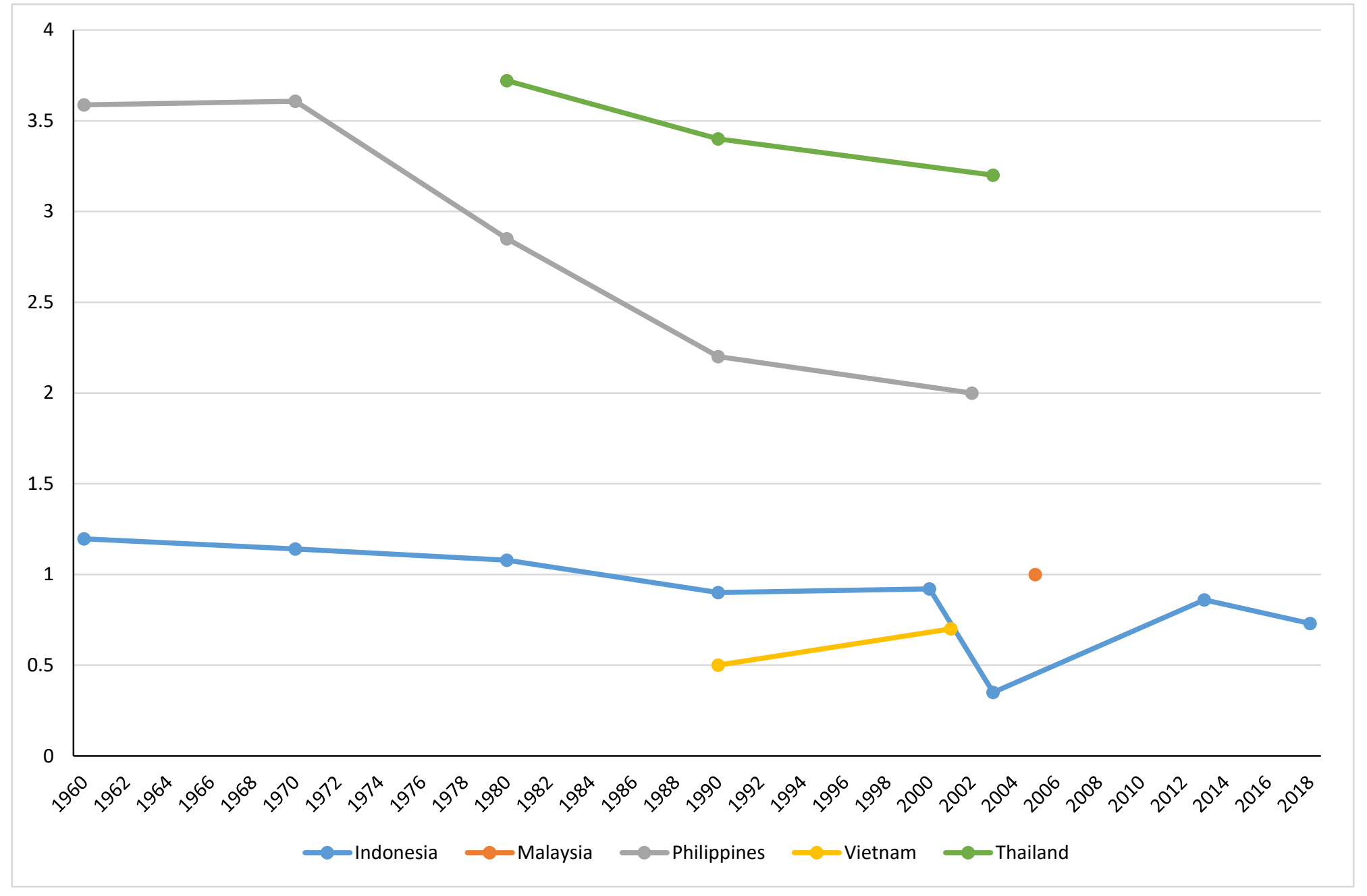

Figure 2. Comparison of changes in average farm size (hectares) in Indonesia, Malaysia, the Philippines, Vietnam, and Thailand Source: Food and Agriculture Organization (various years) and National Statistical Office (2003, 2013, and 2018) for the last three years in Indonesia. 


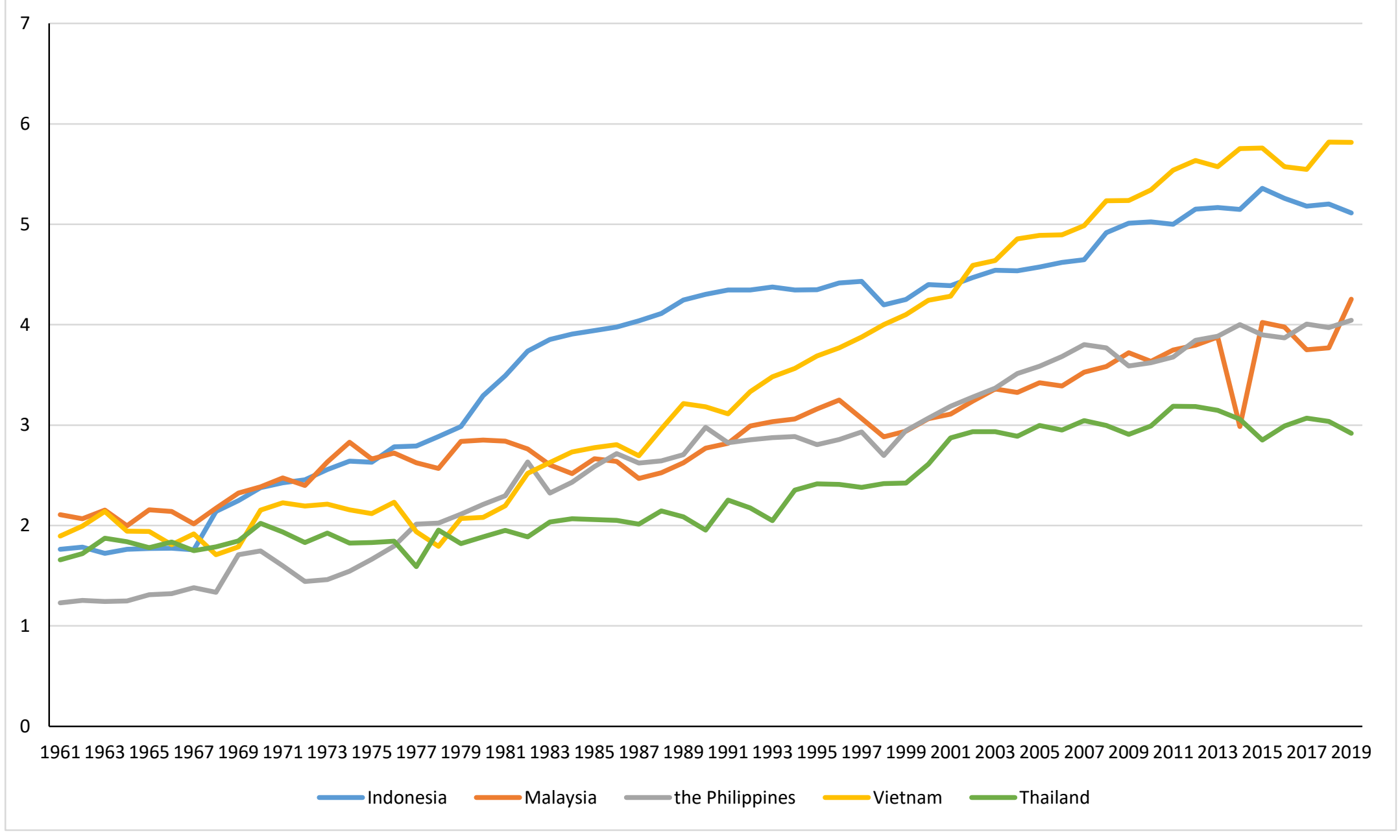

Figure 3. Comparison of changes in paddy yield (ton/hectare) in Indonesia, Malaysia, the Philippines, Vietnam, and Thailand 


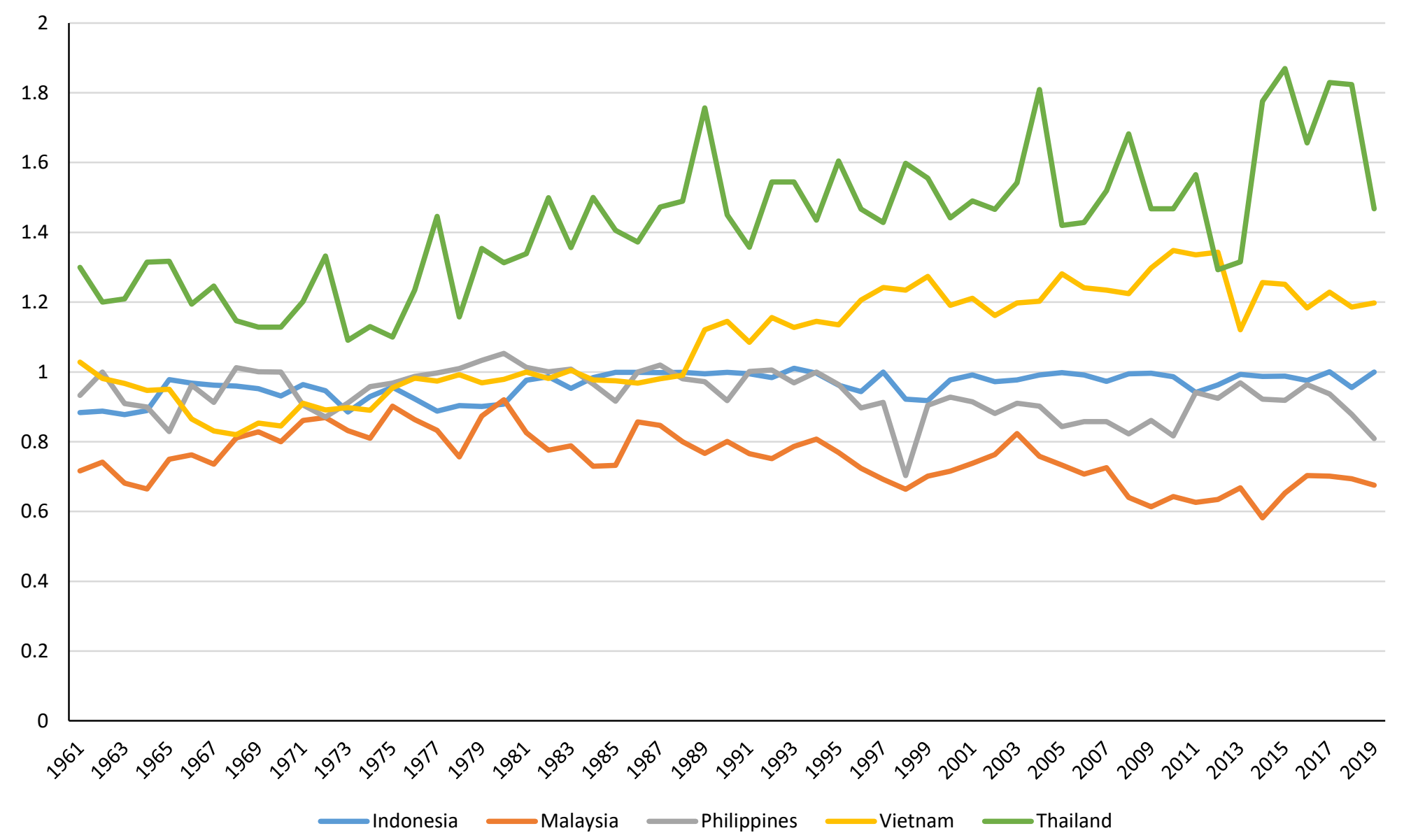

Figure 4. Comparison of changes in rice self-sufficiency ratio in Indonesia, Malaysia, the Philippines, Vietnam, and Thailand Source: FAOSTAT 


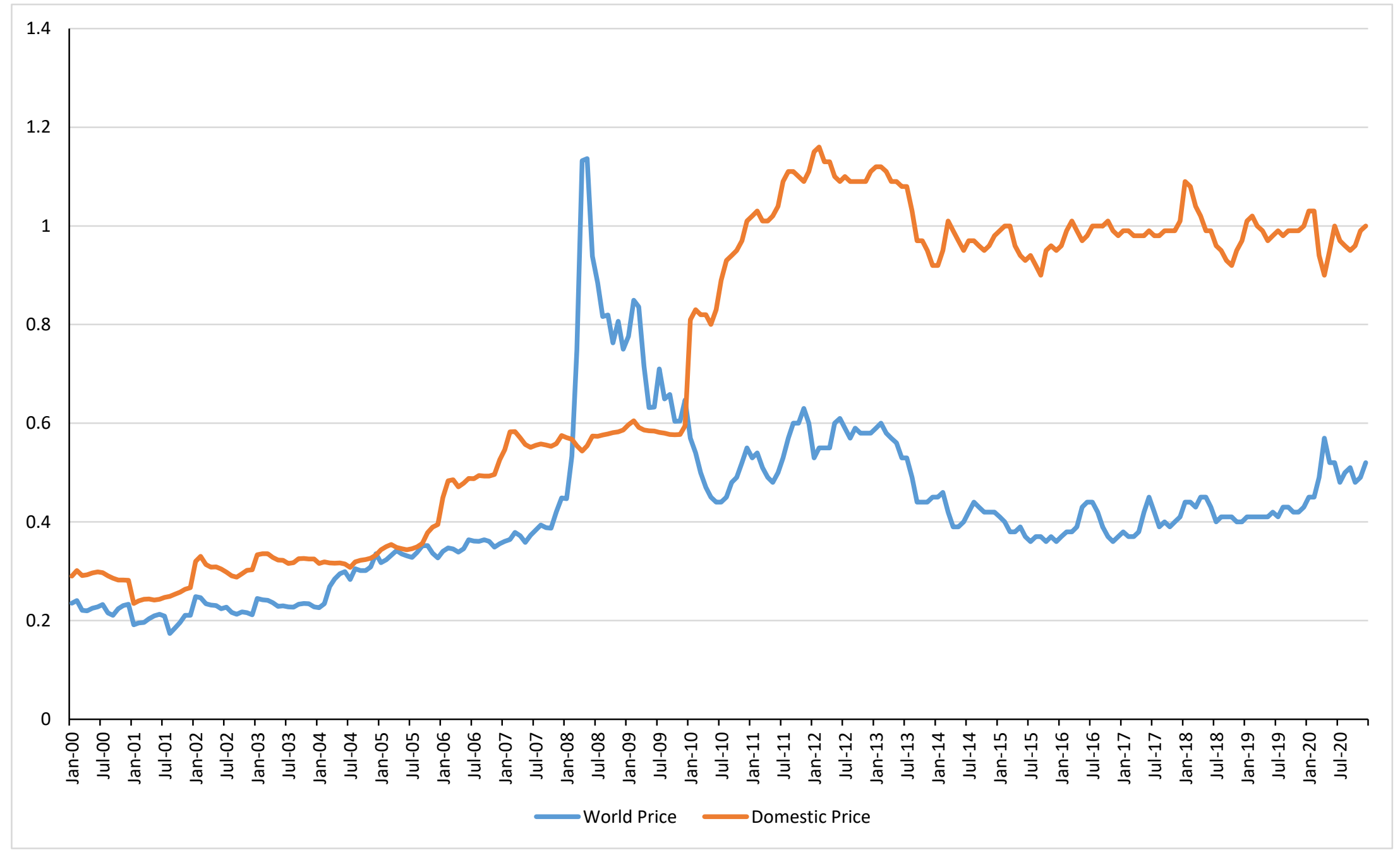

Figure 5. Changes in world and domestic rice prices in Indonesia in terms of US dollars per kilogram Source: Bureau of Statistics (2000-2009), Food and Agriculture Organization (2010-2020) 


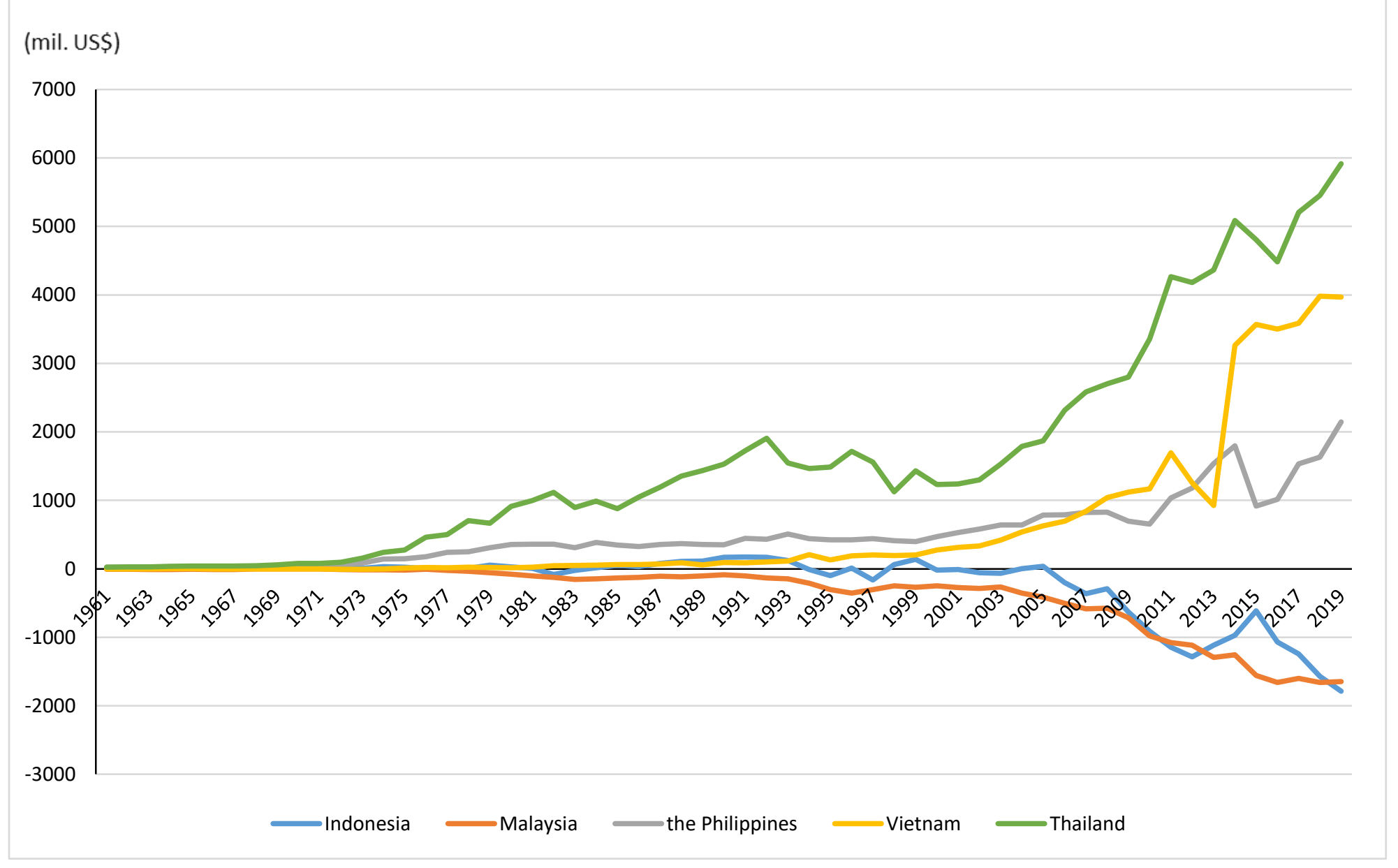

Figure 6. Comparison of changes in net export or net import of fruit and vegetables (million US\$) in Indonesia, Malaysia, the Philippines, Vietnam, and Thailand

Source: FAOSTAT 